\title{
COVID-19 and Private Health: Market and Governance Failure
}

\author{
Owain David Williams ${ }^{1}$
}

Published online: 17 November 2020

(c) Society for International Development 2020

\begin{abstract}
The COVID-19 pandemic has produced mass market failure in global private health, particularly in tertiary care. Low-andmiddle income countries (LMICs) dependent on private providers as a consequence of neglect of national health systems or imposed conditionalities under neoliberal governance were particularly effected. When beds were most needed for the treatment of acute COVID-19 cases, private providers suffered a liquidity crisis, itself propelled by the primary effects of lockdowns, government regulations and patient deferrals, and the secondary economic impacts of the pandemic. This led to a private sector response-involving, variously, hospital closures, furloughing of staff, refusals of treatment, and attempts to profit by gouging patients. A crisis in state and government relations has multiplied across LMICs. Amid widespread national governance failures—either crisis bound or historic — with regards to poorly resourced public health services and burgeoning private health - governments have responded with increasing legal and financial interventions into national health markets. In contrast, multilateral governance has been path dependent with regard to ongoing commitments to privately provided health. Indeed, the global financial institutions appear to be using the COVID crisis as a means to recommit to the roll out of markets in global health, this involving the further scaling back of the state.
\end{abstract}

Keywords Neoliberalism $\cdot$ Private health $\cdot$ Market failure $\cdot$ Governance failure $\cdot$ LMICs

The COVID-19 pandemic very quickly witnessed numerous and catastrophic instances of market failure in health. Much attention has been given to failing supply chains and chaotic international markets for personal protective equipment (PPE), medical masks, gloves and surgical gowns, as well as medical oxygen (Cramton et al. 2020). The consequences of market forces in the lack of vaccine production capacity and decades of under-investment in basic research and vaccine R\&D have also become readily apparent (Butler 2017; Plotkin 2017; Mannix 2020). Poorly trained staff and low standards of care in private long-term aged facilities have failed elderly residents throughout the OECD (Andersson et al. 2018; Bedford et al. 2020; Davidson and Szanton 2020). Yet, of the many market failures in global health experienced during the pandemic, one of the most pivotal and pressing has largely gone unnoticed.

This article examines how the pandemic has produced a mass markets failure in private health services globally,

Owain David Williams

O.D.Williams@leeds.ac.uk

1 School of Political and International Studies, University of Leeds, Leeds, UK particularly in the tertiary or hospital sector. Despite the dearth of analysis of this phenomenon at the time of writing, the extent of this crisis of private health was nonetheless apparent in many low-and-middle income countries (LMICs) very early in the first six months of 2020 (Hellowell et al. 2020), and has also been present within the OECD, particularly in the United States. Private health's market failure has serious implications for pandemic response capacities and for the future of health systems and development in the aftermath of the present viral crisis. Beyond this, I explore how market failure has been met by often chaotic governance and policy responses by states, with indications of many serious fractures in state-firm relations and the thin legitimacy of the public-private partnership model for health systems. At the multilateral level, however, market failure in private health has produced a path-dependent global governance failure in health, which seems set on further supporting and entrenching the role of markets and private provision in LMIC health systems. Market failure has been accompanied by political failure both new and longstanding.

As has been the case with many of the heath market failures detailed above, it can be claimed that mass market failures experienced in private health during the pandemic 
have been long in the making, and have much to do with four decades of neoliberal policies, practices and ideas (Rowden 2013; Stuckler and Basu 2013; Sell and Williams 2019; Sparke 2020). Neoliberal austerity and retreat of the state from health systems have eroded publicly provided health systems and capacities (Labonté and Stuckler 2016; De Ceukelaire and Bodini 2020), with the counterpart marketization, privatization and commodification of healthcare expanding the private provision of health (Schrecker 2016). The 'roll-out' of health markets in LMICs (Sparke 2017; 2020) has also intensified (as it also has in high income countries), with the more recent rise of financialization of health service sectors since the 1990s, this process gathering pace markedly post-Global Financial Crisis with the entrance of hedge funds and investors into the hospital and allied health sectors (Hunter and Murray 2019). Private service provision now accounts for the majority of capacity the national health systems of many LMICs (Mackintosh et al. 2016; McPake and Hanson 2016), with large multisite providers catering more to wealthy patients and medical tourists (Chen and Flood 2013; Mossman et al. 2019). Governance and regulation of the sectors is often weak and fragmented, and frequently in LMICs the private health sectors operate as a parallel and often completely separate system from the public system, and there are huge informational 'black holes' surrounding capacities, services offered and staff employed (Montagu and Goodman 2016). Formal private health providers also serve only small fractions of populations as access is determined by income or selective coverage by insurance schemes. Neoliberalism has seen market-provided healthcare burgeon, and the pandemic has only further exposed what has transpired in health services provision as being inequitable, unstable, and deeply ill-suited to meeting population health needs.

Nonetheless, the realities of the dependence of many countries on the private sector to deliver health is precisely why the issue of market failure is so important in the COVID-19 pandemic. Simply put, when capacities and beds were needed in the viral crisis there was no real alternative to private providers precisely when their business and service models were in crisis. This was proven particularly the case in many LMICs where private hospitals account for nearly $80 \%$ of national capacity in some country examples (WHO 2016). Private sector capacities have been needed in the pandemic, and in new ways, just as the market in healthcare has failed. The private healthcare service and business model has proven disastrous for coordinated national pandemic responses in a number of countries, and ill-suited for universal coverage of those infected by the virus. The liquidity crisis that rapidly confronted private providers in the pandemic meant that we witnessed a spate of service and hospital closures, mass lay-offs of health workers, patients being refused treatment and the withholding of beds, and price gouging of those infected with COVID and seeking care. Financial crisis has cascaded down to problems of service provision and pricing of services. Hollowed-out states have found themselves with eroded public systems for first lines of pandemic response, this precipitating chaotic engagement with private providers as national epidemics gathered pace and health firms grappled with their own market crisis.

This article has two parts. It first details the different components and drivers of the crisis of private health and survey a spectrum of state-level governance responses to provider failure throughout the pandemic. The second half of the article gives focus to multilateral governance, arguing that key institutions have created and promoted the conditions for private sector and market growth in health systems, thus precipitating the present crisis. This governance has also failed to respond after the onset of the pandemic in a manner that will address market failure of population health in LMICs in the near future. This path dependency in global health policy is dangerous for genuine and equitable health security as it is for genuine progress to UHC.

\section{Market Failure in Private Health and State Governance Responses}

The liquidity and service crisis in the sector has seen a chaotic governance response by many LMIC governments. However, states have been forced to intervene in the market in a number of ways, especially in terms of securing access to private sector capacities and on prices charged for COVID-related admissions to hospitals. Public and political anger with private providers escalated through 2020 in many LMICs, percolating upwards to governments and sub-state jurisdictions. This has precipitated a crisis in state-firm relations, and has sparked widespread discussion of the legitimate role of markets and private actors in health service delivery.

While data is still emerging, it is clear that COVID has created an acute liquidity crisis in the private sector internationally, with the impact most felt by smaller and mediumsize practices, clinics and hospitals. Industry bodies have been warning of these private providers facing acute liquidity problems since March 2020, and the financial crisis has forced small- to medium-size clinics and hospitals to close or furlough staff. Even larger multi-site private hospital chains have been affected, although are in a better position to survive and negotiate with governments, especially regarding prices being charged for treating COVID patients. Overall, the private health care sector has faced acute liquidity crises where government support has not been forthcoming.

There were a number of drivers of this acute financial and liquidity crisis in LMICs' private health care sector (Hellowell et al. 2020). First, government emergency regulations 
forced the temporary shutdown of elective and outpatient services, with further uncertainties over when they might be permitted to resume (Kruse and Jeurissen 2020). Second, patients have deferred treatment and procedures due to fear of COVID, or to lockdown measures preventing routine access. Third, economic disruption has meant that insurance or ability to pay out of pocket have both been affected (Hellowell et al. 2020). Fourth, private providers are experiencing rapid cost escalation because of infection control and PPE, and the high cost of medicines and COVID patient treatment (Orissa Post 2020c). Fifth, in some countries private insurers are facing tough challenges due to cancellation of cover (by employers and individuals), and higher claims (Dhara 2020). Thus, some private insurers are deferring or refusing payments to private sector providers just when cash flow is most necessary (Dhara 2020; Soko Directory Team 2020). In addition, in some countries the insurance system is overwhelmed and some state-funded insurance schemes are failing to settle with hospitals in a manner that eases liquidity problems (Amos and Al-Arian 2020; Mohiddin and Temmerman 2020; Loveluck and Salim 2020; Akinwotu 2020). One of the major sources of revenue for private sector hospitals in many LMICs comes from medical tourism, and that this has almost entirely dried up with travel restrictions and the economic fallout of COVID (The Business Research Company 2020; Khoo 2020). Much of the new highly financialized and transnationally-owned investments in hospitals have been attracted to servicing the growing international medical tourist markets (Hunter and Murray 2019; Da Silva 2019).

The private sector responses to this financial crisis were along a spectrum of service failures and attempts to gouge patients and governments. Many hospitals and clinics have been reluctant to take patients who cannot afford co-payment for add-ons not covered in insurance schedules, or to treat patients that might incur high costs to the provider with settlement being uncertain. In India and Kenya there were examples of insurers and insurance bodies capping the amount they are prepared pay for patients being treated in private hospitals and pushing back on the many add-ons (for example, for PPE and oxygen) being billed (Mirror Online 2020; Paliwal 2020; Hisamudin 2020; Nazari 2020; Daily News Egypt 2020). There also seems to be an unwillingness to imperil other services being offered by hospitals because of possible cross-infection, leading to yet further losses from electives and routine procedures having to be cancelled. Beds were hidden from patients and government authorities and patients refused across LMICs in Asia, Africa, India and Latin America (Ang 2020; Ara 2020; Latifi and Heydari 2020; Limpot 2020; MEMO 2020; SABC 2020; Ying 2020).

Even when commitments to preserve proportions of private hospital bed capacity have been secured by governments, firms have gamed the system, and have done so despite state or judicial insistence that they should not. India has been particularly plagued by private hospitals refusing treatment as the public hospital systems in many states have been overrun. Patients have died, sometimes outside hospital doors, after failing to gain admission to multiple hospitals.

More general forms of gouging for COVID treatment by private hospitals across LMICs are evident (Shukla 2020; Jaiswal 2020; Ravi and Babu 2020; Muchetu 2020). The high costs for COVID hospitalizations being reported are not merely a case of hospitals encountering unusually high costs for treatment per COVID case, particularly those needing ICU and ventilation, but are almost certainly a means of offsetting losses initially incurred from the fall-off of elective and out-patient procedures. While cost of per patient treatment for COVID is a moveable feast and surely expensive, hospitals that have gouged in the past appear to be doing so now, in a form of disaster capitalism. We see instances of large up-front deposits being required for hospital admission in India and Kenya (Bhuyan 2020; Soko Directory Team 2020).

In response to these actions and service failures, some states have been forced to respond by intervention in the market through a range of measures and policies, such as emergency legislation, price capping, the sequestration of beds and entire hospitals, and the provision of stability financing. Other governments have chosen more laissez-faire approaches and allowed providers to determine their own relationships with patients and staff. The evidence is mounting of a crisis in state-firm relations in health. The crisis signals the need for a recalibration of LMIC state relations with private healthcare providers and reinvestment in public capacities.

The more laissez-faire, hands off approach to the private sector persists in a range of countries-with governments unwilling or unable to rescue the private sector with emergency cash interventions to provide badly needed liquidity, or to fund the sector through state-based insurance transfers for COVID patients. Many governments and political elites are wedded to the private health model, and indeed have promoted it, and have let hospitals in particular charge what they want for services.

More interventionist policies have been demanded in a range of states, these involving mixtures of emergency regulation, negotiation, threat of sanction, litigation, and political decrees, all directed at securing access to private sector capacities and price capping for COVID treatment. Many ASEAN states responded early and proactively by unilaterally, even aggressively, passing legislation, or simply decreeing limitations on private providers. Malaysia, the Philippines, Thailand and Indonesia all secured COVID treatment by private providers and fixed government subsidized rates (Boonbandit 2020; Loo 2020; Antara 2020; Tiglao 2020). In Egypt, for example, emergency powers were passed on 
22 April to effectively sequester private hospitals for the pandemic response (Reuters 2020). In March 2020 Thailand legislated to prevent private sector from charging COVID patient user fees (The Nation Thailand 2020).

Indian states have moved through their own trajectories of responses to the service and pricing crisis, with even promarket ruling BJP administrations becoming increasingly aggressive toward private providers. Despite multiple states capping prices for treatment of patients, and despite sequestration of beds and capacities by legal means and emergency powers, the situation has been anarchic, with tensions and real divisions emerging between state governments and private providers. Firms are still routinely breaching price caps and gouging, turning away COVID patients and hoarding beds, with repors of unseemly black markets for beds emerging (Orissa Post 2020b, c; Mathew 2020). States have reacted with the sequestration of hospitals, enforced openings, prosecution, and other measures, but circumvention of law and emergency measures have continued through to September 2020, nonetheless (Orissa Post 2020a, b). A number of hospitals have now been seized by state governments for continued breaches.

In other LMICs, private providers with strong market positions and huge hospital capacities in aggregate national terms have been able to exploit government reluctance to intervene in terms of sequestration and the wider need for capacities additional to the public system during the pandemic. These firms have negotiated hard on prices. Added to this, there is suspicion in countries such as Mexico, Brazil, South Africa the UK, India and Peru, that there is complicity in preserving the private model and political and ideological influences at play in the price agreements being settled. Notwithstanding often cosy relationships between the private health sector and governments, some of the government deals for hospital access have been excessive, particularly when compared to the limited financial resources at the disposal of LMICs. South Africa made a high-profile deal with the Big 3 firms dominating the private hospital market, with the multisite Netcare, Mediclinic and Life holding an overwhelming majority share of the nation's stock of hospital beds and ICU capacities. The sector was reported as holding over half of the national critical care beds. Intense negotiations with the South African government saw the three firms holding out for an eventual settlement of Rand 16,000 (US \$950) per day in mid-June (Economic Times 2020). In Peru private providers similarly held out to get $\$ 15,000$ per COVID case; the government agreed to this rate in June (Aquino 2020). Given the poor state of most LMIC national health budgets, these figures represent vast sums leveraged by means of the market power of large provider groups and hospitals and the pandemic needs of governments. Indeed, many governments have not only paid out for access to capacities, but readily bailed out providers in cash crisis, as was the case in the Philippines and Morocco, and is indicated with more laissez faire agreements to transfer revenues to the private providers, as was the case in Mexico (ABS-CBN News 2020; The North Africa Post 2020).

Many governments have themselves neglected their public health systems and have been supportive of or ambivalent to the increasing penetration by financialized private health, particularly in the lower-middle income and middle income-segments of LMIC systems. As a consequence, market failure is built into the balance of services in many countries, and they target more affluent patients to generate higher profits. The startling chaos in countries such as India reveals that governments have not factored in reliance of profit-seeking and market-driven providers into national pandemic preparedness, and the mismatch between private sector reliance in LMICs' national health systems and pandemic emergency needs. The private sector as such is one component of the failure of either emergency or pandemic planning in many states, and yet another damning verdict on the health systems gaps left in place by the global health security agenda and the policies that have rolled back public health. The pandemic has sharply reminded us once again how health policies and increasing privately-focused health systems fail to meet both national needs and those of the most marginalized and vulnerable.

The governance response of many LMICs was to gradually tighten legislative and regulatory measures to enlist private sector participation in national pandemic responses, with particular focus on securing capacities and capping prices charged for COVID treatment. However, it is striking that as the scale of the private sector crisis emerged over 2020, there was little commensurate movement at the multilateral level to rein in the private health providers and refocus global health policy on the public and state as vehicles for health service provision. Indeed, there has been a failure to acknowledge or stress the scale of the liquidity and service crisis in the private sector, and signal the need for fresh health governance approaches that would give greater emphasis to the state and public provision of health services both for less fragile systems for health security and in propoor progress to UHC. Why has multilateral governance failed to respond to these glaring market failures in health?

\section{Multilateral Governance of Private Health: Understanding Governance Failure Before and During the Pandemic}

At the multilateral level the response to the private sector crisis has been markedly different and particularly striking. Indeed, mass market failures in health in the pandemic have, as yet, neither generated any significant shift in the multilateral governance of health and health systems, nor 
a retreat from private health and the partnership model that has largely defined and framed engagement with and promotion of private health in the last two decades (Pauly et al. 2006). Today it seems that neoliberal policies and practices are too deeply embedded in the key multilateral institutions that arbitrate global health policy for them respond to the pandemic crisis of private health by changing course; instead these institutions appear to be doubling down on neoliberal commitments (Youde 2016; Gideon and Unterhalter 2017; Baxter and Casady 2020).

Reviewing recent trends in multilateral health systems governance and policy can help to illuminate the roots of the severe private sector crises under COVID. We need to understand the constructed and financed role of the private sector in areas such as health systems strengthening and UHC (Pfeiffer and Chapman 2019; Prince 2017; Hunter and Murray 2019), all by the direct and indirect means that austerity and debt-driven global economic governance has propelled over the last four decades. Today's multilateral approach is bound by institutional policy approaches and historical ideological orientations to the private sector, markets and health (Sparke 2017). If the private sector survives as a viable entity in national health systems of many LMICs-either financially or politically_it will be due to a large part to multilateral path dependency and political and financial support of the sector, both of which are readily apparent in global health and wider global governance.

The immediate governance responses to the crises of the private sector are only nascent, but there are discernible positive framings and concrete measures to prop up private providers. Beneath immediate and crisis action plans and stability financing, money for training, infrastructure improvements and PPE and other essential supplies, much of 2020 saw a great deal of framing of the crises in the private sector that indicates longer-term ideological and political commitment to the public-private partnership model for health systems. In fact, present multilateral (and donor) framings of 'engaging the private sector in the COVID response' are borrowing readily (and very directly) from recent high-level political commitments expressing the need to engage private the providers in progress to UHC (UN 2019). The re-commitment to the private sector in the COVID crisis, albeit that being tinged with statements of 'the lessons learned' and the 'need for change' in areas such as investment in public health systems and financing for equitable access (Hellowell et al. 2020; WHO 2020), reflect an effective political and policy détente that has been reached among the key multilateral institutions with a governance role in health systems.

The WHO has recognized the wide impact of the private sector financial and service crises under COVID, and has set about establishing means to stabilize and engage private providers in national pandemic response measures
(Hellowell et al. 2020). While admittedly this is still part of a crisis response, in truth it exposes how much WHO has now accepted the central place of the private sector in LMIC health systems. Indeed, WHO has responded to COVID and the financial and service problems facing private healthcare firms and governments by assisting in national audits of capacities lying in the sector; in the support of a Resource House on private providers (run by Impact for Health, and amounting at present to no more than a very useful digest of news reports of private sector problems in a range of countries); and a few national studies (Kenya and Rwanda) focused on government and Ministries of Health experience of harnessing the private sector in the COVID response. ${ }^{1}$ While the private sector the crises is acknowledged, the policy response to the longer-term role of the private sector in LMIC health systems has been conspicuously absent.

Apart from this, WHO has linked its private sector response to the newly-badged Health Systems Governance and Financing Department (HSGF), and the Advisory Group on the Governance of the Private Sector for UHC (AG). This convened in 2019 to provide advice as to the regulation and engagement of the private health sector in SDG commitment to Universal Health Coverage. The pandemic has seen the Advisory Group, Impact for Health and HSGF constitute and assemble the WHO's Private Health Sector for COVID-19 Initiative (WHO 2020), this involving a three-phase plan starting with rapid audits of capacities and dialogue, through to offering 'a rapid, real-time, evidence-based, tailored support to countries that will seek to improve private health sector engagement' in pandemic responses, these directed at constituting an appropriate 'whole-of-government' and 'whole-of-society' approaches (WHO 2020).

But evidence of concrete measures and successes of private engagement on the ground and in national contexts looks very scanty and largely rhetorical at present, at least from the standpoint of WHO's own direct involvement in such activities. Criticism of the private sector's numerous failures in the pandemic are totally absent from WHO public statements.

However, the framing and institutional remits are telling here, and there is no change of course apparent in WHO recent positions on engagement with the private sector for UHC as compared to the statements on the need to do the same for a COVID response. What WHO stated and committed to in terms of 'the need for engagement with the private sector' in the 2019 UNGA Political Declaration on UHC has been repurposed for the COVID crisis (UN 2019) The WHO has shifted the focus of policy to financing arrangements for UHC, to new arrangements for collecting and pooling

\footnotetext{
$\overline{1}$ https://impactforhealth.com/project/engaging-the-private-healt h-sector-in-covid-19-response/.
} 
resources, including government, employer and social insurance, and, by doing so, has redirected health systems policy away from the question of who is delivering health. The particular public or private mode of service delivery becomes far less important, replaced by a rather bland focus on quality services and coverage by means of essential and other packages of health. Notwithstanding commitments with regard to removing financial barriers to access and direct payments for healthcare, financing arrangements have come to be seen as the new important instrument by which to secure access for all irrespective of the service provider. These shifts are far from arcane and technical, and rather reflect an ideological and policy retreat by WHO from primary health and publicly provided health, all toward less of an emphasis on the particular mode of health service delivery.

The WHO has undergone a substantial institutional and ideological shift with regard to policy and practical commitments to publicly provided health services. The shift within WHO, particularly in the Health Systems Division, dates back over a decade. Indeed, present positioning about the need to engage and secure the private sector as a component in COVID response represents more than just a realistic and 'real time' assessment that the private sector is desperately needed in terms of capacities for COVID (WHO 2020). Rather, the response to the private sector in the present crisis reflects the effective détente and shift in WHO's position toward the wider multilateral economic governance framing in which the market has been accepted as part of the solution to perceived government failures in providing and allocating healthcare. WHO has become divorced from its own historical position on the private sector in health to align with other major multilateral actors and donors, and this shift, particularly away from primary care for UHC, and to financing for UHC is apparent when one compares the radically different World Health Reports of 2008 and 2010 (Van Lerberghe 2008; WHO 2010). To be sure, this and WHO's wider position on financing for UHC reflects the wider ascendancy of the public-private model in neoliberal national and global health governance, this thinly veiling a more market-oriented set of government and firm relationships in which the private was permitted to expand its share. This also speaks to the private sector's more recent framing as an essential part of progress toward UHC by WHO and other actors.

In contrast, the World Bank Group and IMF have been more active in the global health governance of health systems in LMICs during the pandemic, committing large multibillion dollar sums to grants and loans, some of which have been targeted at health assistance and pandemic response. Unlike WHO, the Bank was able to put money on the ground in a range of LMICs. In April 2020 the bank announced a 15-month programme of pandemic response and economic recovery worth $\$ 160$ billion and immediate crisis response sums totalling $\$ 14$ billion, six billion of which was targeted at health systems emergency responses (Engel et al. 2020; Oxfam 2020). Many of the projects approved to date are for health and health systems. Much of the immediate support went to the supply of badly needed medical technologies, PPE, vaccine partnerships, surveillance capacities and staff training. But there are also infrastructural and health systems investments for LMIC health (World Bank COVID-19 project data at World Bank 2020a).

The World Bank frontloaded grants through their COVID-19 Fast Track Facility with more lending to follow over an extended COVID response. As of June 2020, the Bank had approved loans and grants totalling \$14 billion in 60 countries through their new Fast Track Facility. These loans aim to "help countries respond to immediate health consequences of the pandemic and bolster economic recovery' (World Bank 2020b). Out of these sums, the International Bank for Reconstruction and Development (IBRD targets Middle-Income Country lending) and the IDA were allocated $\$ 2.8$ billion and $\$ 3.8$ billion respectively, while the Bank's private sector arm, the International Financial Corporation (IFC), was allocated a large $\$ 8$ billion to support the private sector (Engel et al. 2020). The IFC facility is also significant in health terms as it has been at the forefront of facilitating the financialization of health sectors, particularly in low-middle income and middle-income countries. It has launched a US\$4 billion medical supply platform and the Real Sector Crisis Response Facility (World Bank 2020c; IFC 2020). Under this latter instrument, refinancing and stability loans are flowing to private sector providers and other wider private sector businesses and banks. A large proportion of the health provider loans are targeted at easing liquidity problems-such as a US\$ 4 million loans to CIEL Healthcare, a medical and diagnostic service provider based in Mauritius and Uganda, with investments in the Nigerian (Hong Kong listed) multisite hospital provider Hygeia Health Group, and US\$70 million to the Bolivian Healthcare Network Service Project (World Bank 2020a). These are also only the beginning of considerable further investments and after the immediate emergency of the first wave recedes there will be a greater focus on health systems strengthening.

The World Bank itself is deploying much more money than any of the investment arms. This includes US\$ 7.5 million to the Fijian health system; and \$1 billion to India (including money to revamp ICU facilities, wards, infectious disease hospitals, and laboratory capacities); \$500 million to the Philippines; \$200 million to Pakistan; and \$350 million to the Ukraine (World Bank 2020a). Not all these grants and loans cover health systems and responses, but portions of the large raft of COVID response monies are for health infrastructures and emergency capacities. While clearly not ostensibly private sector provider stabilization 
funds, it seems inevitable that government-held money will be channelled via governments to private hospital firms, not least to secure private sector participation in service delivery within the pandemic, and in the aftermath of the pandemic will reflect that private health is a key part of World Bank imagining of national systems under its 'maximising finance for development (MFD) program'. ${ }^{2}$ Indeed, in April 2020 the World Bank President, David Malpass, was framing COVID recovery money in terms of the need for more investment in private and market-driven health, and it appears that loan conditionalities might be echoing this ideological and policy commitment (World Bank 2020d).

Most of the funds have been provided as highly concessional investment loans, and not development policy loans as budget support instruments. While many of the loans for COVID response are to governments, such government investments may be distributed to private sector entities to pay for health services. Indeed, both IMF and World Bank loans since the COVID crisis have largely suspended investment criteria, and governments have 'flexibility' in how loans are used. Increased less concessional loans will follow these initial investments. Moreover, the loans will mean greater government debt and less public finance fiscal space, and notwithstanding the fact that at least some of the present loans offer favourable repayment periods and interest, money from the Bank (and IMF certainly) will be added to national deficits.

Indeed, the past is instructive here. Historically, debt conditionalities have shifted from roll-back austerity policies for health, infrastructure and social sectors, involving austerity and state withdrawal (as well as wage capping in the public sector), to post-structural adjustment policies that have promoted public-private blended health systems (Sparke 2020). The market 'roll out' in health has also involved the ongoing expansion of private investment in health, particularly in tertiary and allied sectors (Sparke 2017, 2020). Health has been a key sector that has been at the centre of this double movement, of removing the state to let the market into lead. The IFC has been critical to the financialization process in the latter roll-out market phase, assiduously courting and facilitating investment to plug the trillion dollar investment gaps in LMIC health (Hunter and Murray 2019; Sparke 2017; 2020).

The World Bank's own direction in the COVID response must be understood in terms of its effective partnership the IMF. The IMF has up to USD $\$ 1$ trillion for loans to respond to COVID and recover (IMF 2020). The IMF approved 77 loans after the pandemic commenced to June 2020 via new or adapted existing loan programmes. De

\footnotetext{
2 http://documents1.worldbank.org/curated/en/168331522826993 264/pdf/124888-REVISED-BRI-PUBLIC-Maximizing-Finance.pdf.
}

facto conditionalities are attached to the present raft of emergency lending, with expectations that many recipients of the 'COVID lending' will commence resettlement and budget balancing as early as 2021 (Bretton Woods Project 2020). Billion dollar emergency funding to Egypt, Jordan, Ukraine, and some of the 90 countries that have asked for COVID-related emergency assistance, is coming with conditionalities (Bretton Woods Project 2020). These are not only shrinking future policy and financial space for investing in health workforce and public systems, but are insisting on fiscal consolidation, involving in many LMICs further rounds of cuts to public wages and social and welfare spending (Engel et al. 2020). The IMF and the World Bank are trying to lock out the state and public spending, and lock in the market for provision of welfare goods and are doing so in the pandemic. So despite the market failure and the crisis of private sector health, it has received a great deal of indirect and direct policy and financial support, and positive signalling of support for present and future investors. The IMF has also used loans in recent years to insist on hospital privatizations, in Pakistan, for example, in 2019, or on huge cuts to public hospital funding, as in Ecuador in the same year (Engel et al. 2020). Current bailouts and lending will intensify these pressures and there is widespread suspicion of the Bank and IMF's intentions with regard to furthering the role of the private sector and markets in health (Kentikelenis et al. 2020).

\section{Conclusion}

As the financial crisis facing the private sector intensifies as the pandemic unfolds in LMICs, many governments are currently seeking to rein in service failures and price gouging, or are simply unable to harness private sector capacities in coherent national responses. The failure in health systems governance at the state and multilateral levels abnegates our collective human right to health for all. We may ask where is $\mathrm{WHO}$ in the process of detailing private sector market failure? And why is it that manifest market failure in private health is not the spur for refocusing the organization's policies with regard to private healthcare or the role of the state in ensuring widely available and equitable services, and in building toward genuine health security and UHC?

While markets have been allowed into national health systems, often by means of new financing arrangements and partnership models, as the 2008 World Health Report identified, the COVID crisis has found the private sector service model to be profoundly unstable and narrow, illsuited to service continuity, access and population coverage in a viral crisis. While populations and healthcare workers in LMICs and Higher Income Countries alike are demanding better public investment in public health systems as a 
key response to the market failures witnessed in the COVID crisis, and for the curtailment of market-provided health by means up to nationalization, the WHO and other agencies appear path-dependent and bound to the illusory PPP model. If the private sector survives the pandemic, then it must be on new terms and with much more burdensome governance and regulatory arrangements in place. Intervention in the sector by states and multilateral donors should be more than enough leverage to secure a new settlement. Nationalization and the need for greater publicly provided services are clear alternatives to dragging the private sector into new accommodation.

However, it is clear that the crises in private health has also signalled the deeper and more fundamental mismatch of health to its provision by a market system. At worst the pandemic has clearly magnified weaknesses and the market failures embedded in market systems for health, and at worst it has shown the dangerous dependence on a system too flawed and too weak for either universal coverage or health crisis interventions. It seems that whatever national and public sentiments regarding private sector failure, key actors in the global governance of health and health system seem ready to reproduce the market-driven models and policies of recent decades, and are already actively embedding new sets of conditionalities to donor assistance and loans that will further shrink the public in health in LMICs.

\section{References}

$A B S$-CBN News. 2020. Private sector workers to receive P5,000 aid amid COVID-19 pandemic-DOLE. ABS-CBN News. 25 March. https://news.abs-cbn.com/news/03/25/20/private-sector-workersto-receive-p5000-aid-amid-covid-19-pandemic-dole.

Akinwotu, Emmanuel. 2020. Nigeria to cut healthcare spending by $40 \%$ despite coronavirus cases climbing. The Guardian. 10 June. https ://www.theguardian.com/global-development/2020/jun/10/niger ia-to-cut-healthcare-spending-by-40-despite-coronavirus-cases -climbing.

Andersson, Åsa, Catharina Frank, Ania M. Willman, Per-Olof Sandman, and Görel Hansebo. 2018. Factors contributing to serious adverse events in nursing homes. Journal of Clinical Nursing 27: e354-e362.

Amos, Deborah, and Lama Al-Arian. 2020. Amid Lebanon's Economic Crisis, The Country's Health Care System Is Ailing. National Public Radio. https://www.npr.org/2020/02/09/800410394/amid-leban ons-economic-crisis-the-countrys-health-care-system-is-ailing.

Ang, Cynthia. 2020. Oman: Private hospitals cannot turn away COVID-19 patients. Middle East Insurance Review. 7 July. https ://www.meinsurancereview.com/News/View-NewsLetter-Artic le id $=72520 \&$ Type $=$ MiddleEast.

Antara. 2020. State, Private Hospitals Ready to Contain COVID-19: Govt. Tempo. co. 18 March. https://en.tempo.co/read/1320850/ state-private-hospitals-ready-to-contain-covid-19-govt.

Aquino, Marco. 2020. Peruvian government strikes agreement with private clinics on COVID care. Reuters. 25 June. https://www. reuters.com/article/us-health-coronavirus-peru/peruvian-gover nment-strikes-agreement-with-private-clinics-on-covid-careidUSKBN23W2E8.

Ara, Ferdous. 2020. Private hospitals continue to refuse COVID-19 patients in Chattogram. New Age. 1 June. https://www.newagebd. net/article/107421/private-hospitals-continue-to-refuse-covid-19patients-in-chattogram.

Baxter, David, and Carter B. Casady. 2020. Proactive and Strategic Healthcare Public-Private Partnerships (PPPs) in the Coronavirus (Covid-19) Epoch. Sustainability, 12(12): 5097. MDPI AG. http:// dx.doi.org/10.3390/su12125097.

Bedford, Juliet, Delia Enria, Johan Giesecke, David L. Heymann, Chikwe Ihekweazu, Gary Kobinger, et al. 2020. COVID-19: Towards controlling of a pandemic. The Lancet 395: 1015-1018.

Bhuyan, Anoo. 2020. Covid Patients' Claims Denied As Insurers, Private Hospitals Battle Over Bills. Bloomberg. 29 September. https ://www.bloombergquint.com/coronavirus-outbreak/covid-patie nts-claims-denied-as-insurers-private-hospitals-battle-over-bills.

Boonbandit, Tappanai. 2020. Gov't Says Private Hospitals Can't Charge COVID-19 Treatment. 6 April. https://www.khaosodeng lish.com/news/business/2020/04/06/govt-says-private-hospitalscant-charge-covid-19-treatment/.

Bretton Woods Project. 2020. The IMF and World Bank led COVID19 recovery. Building back better or locking in broken policies? https://www.brettonwoodsproject.org/2020/07/the-imf-and-world -bank-led-covid-19-recovery-building-back-better-or-locking-inbroken-policies/.

Butler, Decla. 2017. Billion-dollar project aims to prep vaccines before epidemics hit. Nature News 541 (7638): 444-445.

Chen, Y.Y.Brandon, and Colleen M. Flood. 2013. Medical Tourism's Impact on Health Care Equity and Access in Low-and middleincome Countries: Making the Case for Regulation. The Journal of Law, Medicine \& Ethics 41 (1): 286-300.

Cramton, Peter, Axel Ockenfels, Alvin E. Roth, and Robert B. Wilson. 2020. Borrow crisis tactics to get COVID-19 supplies to where they are needed. Nature, 18 June, 582: 334-336.

Da Silva, Chantal. 2019. Thousands of Americans are Crossing the Border Into Mexico Every Year to Get Affordable Medical Treatment. Newsweek. 18 May. https://www.newsweek.com/thous ands-americans-cross-border-mexico-affordable-medical-treat ment-each-1426943.

Daily News Egypt. 2020. Some private hospitals sell COVID-19 plasma at inflated prices: MP. 13 June. https://dailynewsegypt. com/2020/06/13/some-private-hospitals-sell-covid-19-plasma-atinflated-prices-mp/.

Davidson, Patricia M., and Sarah L. Szanton. 2020. Nursing homes and COVID-19: We can and should do better. Journal of Clinical Nursing 29 (15-16): 2758-2759. https://doi.org/10.1111/ jocn. 15297.

De Ceukelaire, Wim, and Chiara Bodini. 2020. We Need Strong Public Health Care to Contain the Global Corona Pandemic. International Journal of Health Services 50 (3): 276-277. https://doi. org/10.1177/0020731420916725.

Dhara, Tushar. 2020. India's shift to insurance-led private healthcare weakens its ability to combat COVID-19: Experts. The Caravan. 29 March. https://caravanmagazine.in/health/india-shift-to-insur ance-led-private-healthcare-weakens-its-ability-to-combat-covid.

Economic Times. 2020. South Africa government, private hospitals agree deal on COVID-19 patients. 8 June. https://health.econo mictimes.indiatimes.com/news/hospitals/south-africa-government -private-hospitals-agree-deal-on-covid-19-patients/76251842.

Engel, Susan, Nadine Madkour, and Owain D. Williams. 2020. The World Bank's response to COVID-19. https://jubilee.worldsecur esystems.com/_literature_167253/The_World_Bank's_Respo nse to Covid-19.

Gideon, Jasmine, and Elaine Unterhalter. 2017. Exploring public private partnerships in health and education: a critique. Journal of 
International and Comparative Social Policy 33 (2): 136-141. https://doi.org/10.1080/21699763.2017.1330699.

Hellowell, Mark, Andrew Myburgh, Mirja Sjoblom, Srinivas Gurazada, and Dave Clarke. 2020. Covid-19 and the collapse of the private health sector: a threat to countries' response efforts and the future of health systems strengthening? https://ghpu.sps.ed.ac.uk/covid -19-and-the-collapse-of-the-private-health-sector-a-threat-tocountries-response-efforts-and-the-future-of-health-systems-stren gthening/.

Hisamudin, Hakimie Amrie. 2020. Fight private hospitals' greed, insurance firms told amid probe into RM200 fee for masks. Free Malaysia Today. 21 May. https://www.freemalaysiatoday.com/ category/nation/2020/05/21/fight-private-hospitals-greed-insur ance-firms-told-amid-probe-into-rm200-fee-for-masks/.

Hunter, Benjamin M., and Susan F. Murray. 2019. Deconstructing the Financialization of Healthcare. Development and Change 50 (5): 1263-1287. https://doi.org/10.1111/dech.12517.

International Finance Corporation (IFC). 2020. IFC and COVID-19. https://www.ifc.org/wps/wcm/connect/news_ext_content/ifc_exter nal_corporate_site/news+and+events/covid-19.

Jaiswal, Pooja Biraia. 2020. How Mumbai's private hospitals are fleecing COVID-19 patients. The Week. 9 June. https://www.thewe ek.in/news/india/2020/06/09/how-mumbai-private-hospitals-arefleecing-covid-19-patients.html.

Kentikelenis, Alexander, Daniela Gabor, Isabel Ortiz, Thomas Stubbs, Martin McKee, and David Stuckler. 2020. Softening the blow of the pandemic: will the International Monetary Fund and World Bank make things worse? The Lancet Global Health 8 (6): e758-e759.

Khoo, Daniel. 2020. Pandemic clouds private hospital outlook. The Star. 11 April. https://www.thestar.com.my/business/businessnews/2020/04/11/pandemic-clouds-private-hospital-outlook.

Kruse, Florien Margareth, and Patrick P.T. Jeurissen. 2020. For-profit hospitals out of business? Financial sustainability during the COVID-19 epidemic emergency response. International Journal of Health Policy and Management 9 (10): 423-428.

Labonté, Ronald, and David Stuckler. 2016. The rise of neoliberalism: how bad economics imperils health and what to do about it. Journal of Epidemiology and Community Health 70 (3): 312-318.

Latifi, Ali M., and Roya Heydari. 2020. Coronavirus and Iran: Hospitals refusing to treat Afghans living in the country. Middle East Eye. 20 March. https://www.middleeasteye.net/coronavirus-iranhospitals-refusing-treat-afghans.

Limpot, Kristel. 2020. Duterte orders probe on hospitals refusing COVID-19 patients. CNN Philippines. 17 April. https://www. cnnphilippines.com/news/2020/4/17/Duterte-probe-hospital-refus ing-covid-patients.html.

Loo, Cindi. 2020. RM200,000 compound issued to private hospital that overcharged face masks. The Sun Daily. 22 May. https://www. thesundaily.my/local/rm200000-compound-issued-to-privatehospital-that-overcharged-face-masks-yg2448346.

Loveluck, Louisa, and Mustafa Salim. 2020. Iraq's economy is collapsing under the double blow of sinking oil prices and coronavirus lockdown. The Washington Post. 5 May. https://www.washi ngtonpost.com/world/middle_east/iraqs-economy-is-collapsing -under-the-double-blow-of-sinking-oil-prices-and-coronaviru s-lockdown/2020/05/04/61b26a3e-8897-11ea-80df-d24b35a568 ae_story.html.

Mannix, Liam. 2020. Vaccine development is a case of 'market failure'. Here's why. Sydney Morning Herald, 13 April. https://www.smh. com.au/national/vaccine-development-is-a-case-of-market-failu re-here-s-why-20200413-p54jez.html.

Mackintosh, Maureen, Amos Channon, Anup Karan, Sakthivel Selvaraj, Eleonora Cavagnero, and Hongwen Zhao. 2016. What is the private sector? Understanding private provision in the health systems of low-income and middle-income countries.
The Lancet 388 (10044): 596-605. https://doi.org/10.1016/ S0140-6736(16)00342-1.

Mathew, Ashlin. 2020. Profit in times of COVID-19: Is it time to take over private hospitals? National Herald. 20 June. https://www. nationalheraldindia.com/india/profit-in-times-of-covid-19-is-ittime-to-take-over-private-hospitals.

McPake, Barbara, and Kara Hanson. 2016. Managing the publicprivate mix to achieve universal health coverage. The Lancet 388 (10044): 622-630. https://doi.org/10.1016/S0140 $-6736(16) 00344-5$

MEMO. 2020. Anger in Egypt over hospitals' rejection to treat woman infected with COVID-19. Middle East Monitor. 30 May. https://www.middleeastmonitor.com/20200530-anger-in-egypt -over-hospitals-rejection-to-treat-woman-infected-with-covid $-19 /$.

Mirror Online. 2020. Wait, what? Rs 27,000 charged in three days for PPE kits at Kalyan private hospital. Mumbai Mirror. 29 June. https://mumbaimirror.indiatimes.com/coronavirus/news/waitwhat-rs-27000-charged-in-three-days-for-ppe-kits-at-kalyan-priva te-hospital/articleshow/76682836.cms.

Mohiddin, Abdu, and Marleen Temmerman. 2020. COVID-19 exposes weaknesses in Kenya's healthcare system. And what can be done. The Consersation. 28 July. https://theconversation.com/covid-19exposes-weaknesses-in-kenyas-healthcare-system-and-what-canbe-done-143356.

Montagu, Dominic, and Catherine Goodman. 2016. Prohibit, constrain, encourage, or purchase: how should we engage with the private health-care sector? The Lancet 388 (10044): 613-621. https://doi. org/10.1016/S0140-6736(16)30242-2.

Mossman, Kathryn, Anita M. McGahan, Will Mitchell, and Onil Bhattacharyya. 2019. Private Sector Entrepreneurship in Global Health: Innovation, Scale and Sustainability. Toronto: University of Toronto Press.

Muchetu, Robin. 2020. Materdei demands hefty US\$ deposits for Covid-19 patients. The Zimbabwe Daily. 2 July. https://thezi mbabwedaily.com/news/494894-materdei-demands-hefty-usdeposits-for-covid-19-patients.html.

Nazari, Tazneem. 2020. Private Hospital In KL Under Investigation For Overpriced Face Masks. The Rakyat Post. 16 May. https://www. therakyatpost.com/2020/05/16/private-hospital-in-kl-under-inves tigation-for-overpriced-face-masks/.

Orissa Post. 2020a. Identifying private hospitals to treat COVID-19 patients for free or at nominal cost: Supreme Court tells Centre. Orissa Post. 27 May. https://www.orissapost.com/identify-priva te-hospitals-to-treat-covid-19-patients-for-free-or-at-nominalcost-supreme-court-tells-centre/.

Orissa Post. 2020b. Few private hospitals doing 'black marketing of beds', refusing admission to COVID patients: Kejriwal. Orissa Post. 6 June. https://www.orissapost.com/few-private-hospitalsdoing-black-marketing-of-beds-refusing-admission-to-covid-patie nts-kejriwal/.

Orissa Post. 2020c. Private hospitals to bear COVID-19 treatment cost. Orissa Post. 24 June. https://www.orissapost.com/private-hospi tals-to-bear-covid-19-treatment-cost/.

Oxfam 2020. Fighting inequality in the time of COVID-10. The commitment to reducing inequality index 2020. https://oxfamilibrary. openrepository.com/bitstream/handle/10546/621061/rr-fightinginequality-covid-19-cri-index-081020-en.pdf.

Paliwal, Aishwarya. 2020. As private hospitals charge lakhs for PPE kits, masks, Covid patients take loans to pay huge bills. India Today. 12 June. https://www.indiatoday.in/india/story/coronaviru s-private-hospitals-charging-lakhs-for-mask-ppe-patients-strug gle-to-pay-bills-1688119-2020-06-12.

Pauly, Mark.V., Peter Zweifel, Richard M. Scheffler, Alexander S. Preker, and Mark Bassett. 2006. Private health insurance in developing countries. Health Affairs 25 (2): 369-379. 
Pfeiffer, James, and Rachel R. Chapman. 2019. NGOs, austerity, and universal health coverage in Mozambique. Globalization and Health 15 (1): 1.

Plotkin, Stanley A. 2017. Vaccines for epidemic infections and the role of CEPI. Human Vaccines \& Immunotherapeutics 13 (12): $2755-2762$.

Prince, Ruth J. 2017. Universal Health Coverage in the Global South: New models of healthcare and their implications for citizenship, solidarity and the public good. Michael 14 (2): 153-172.

Ravi, Sidharth, and Nikhil M. Babu. 2020. Coronavirus I Price of admission at Delhi's private hospitals. The Hindu. 14 June. https ://www.thehindu.com/news/cities/Delhi/price-of-admission/artic le31829015.ece.

Reuters 2020. Egypt amends emergency laws amid coronavirus outbreak. 22 April. https://www.reuters.com/article/us-health-coron avirus-egypt-lawmaking-idUSKCN22437A.

Rowden, Rick. 2013. The deadly ideas of neoliberalism: how the IMF has undermined public health and the fight against AIDS. London: Zed Books Ltd.

SABC. 2020. Eastern Cape Health condemns refusal to treat COVID19 patients. SABC. 9 May. https://www.sabcnews.com/sabcnews/ eastern-cape-health-condemns-refusal-to-treat-covid-19-patients/.

Schrecker, Ted. 2016. Globalization, austerity and health equity politics: taming the inequality machine, and why it matters. Critical Public Health 26 (1): 4-13. https://doi.org/10.1080/09581 596.2014 .973019

Sell, Susan K., and Owain D. Williams. 2019. Health Under Capitalism: A global political economy of structural pathogenesis. Review of International Political Economy 27 (1): 1-25. https:// doi.org/10.1080/09692290.2019.1659842.

Shukla, Raghwendra. 2020. Beyond Reach Of Common Man: Max Hospital Gurgaon's Exorbitant Rate Card For COVID-19 Patients Goes Viral. Health Wire. 12 June. https://www.healthwire.co/ beyond-reach-of-common-man-max-hospital-gurgaons-exorb itant-rate-card-for-covid-19-patients-goes-viral/.

Soko Directory Team. 2020. We won't pay for Covid-19 treatment in private Hospitals-insurers. 16 June. https://sokodirectory. com/2020/06/we-wont-pay-for-covid-19-treatment-in-privatehospitals-insurers/.

Sparke, Matthew. 2020. Neoliberal regime change and the remaking of global health: from rollback disinvestment to rollout reinvestment and reterritorialization. Review of International Political Economy 27 (1): 48-74. https://doi.org/10.1080/09692290.2019.1624382.

Sparke, Matthew. 2017. Austerity and the embodiment of neoliberalism as ill-health: Towards a theory of biological sub-citizenship. Social Science and Medicine 187: 287-295. https://doi. org/10.1016/j.socscimed.2016.12.027.

Stuckler, David, and Sanjay Basu. 2013. The body economic: why austerity kills: recession, budget battles, and the politics of life and death. London: Penguin Press.

The Business Research Company. 2020. Medical Tourism Market Global Report 2020-30: Covid 19 Growth and Change. https:// www.thebusinessresearchcompany.com/report/medical-tourismmarket-global-report-2020-30-covid-19-growth-and-change.

The Nation Thailand. 2020. Private medical facilities told of new rules on Covid-19. 13 March. https://www.nationthailand.com/ news/30384016.
The North Africa Post. 2020. COVID-19: Morocco to compensate 700,000 private sector workers hit by confinement. 2 April. https ://northafricapost.com/39624-covid-19-morocco-to-compensate -700000-private-sector-workers-hit-by-confinement.html.

Tiglao, Rigoberto. D. 2020. Convert selected private hospitals into dedicated Covid-19 centers. The Manila Times. 23 March. https:// www.manilatimes.net/2020/03/23/opinion/columnists/topanalysis/ convert-selected-private-hospitals-into-dedicated-covid-19-cente rs/705090/.

UN. 2019. UN High Level Meeting on Universal Health Coverage: Moving together to build a healthier world, political declaration. https://www.un.org/pga/73/wp-content/uploads/ sites/53/2019/05/ UHC-Political-Declaration-zero-draft.pdf.

Van Lerberghe, Wim. 2008. The world health report 2008: primary health care: now more than ever. World Health Organization.

World Bank. 2020a. World Bank Group's Operational Response to COVID-19 (coronavirus)-Projects List.

World Bank. 2020b. Annual Report: Responding to the COVID-19 pandemic. https://www.worldbank.org/en/about/annual-report/ covid-response.

World Bank. 2020c. Report to the board of directors on a proposed investment in IFC fast track COVID-19 Facility World Region. http://documents1.worldbank.org/curated/pt/166621584551201 643/pdf/Report-to-the-Board-of-Directors-on-a-Proposed-Inves tment-in-IFC-Fast-Track-Covid-19-Facility-World-Region.pdf.

World Bank. 2020d. World Bank Group President David Malpass: Remarks to G20 Finance Ministers. 15 April. https://www.world bank.org/en/news/statement/2020/04/15/world-bank-group-presi dent-david-malpass-remarks-to-g20-finance-ministers.

WHO. 2016. Role and contribution of the private sector in moving towards universal health coverage/World Health Organization. Regional Office for the Eastern Mediterranean.

WHO. 2010. The world health report: health systems financing: the path to universal coverage: executive summary (No. WHO/IER/ WHR/10.1). World Health Organization.

WHO. 2020. Supporting private sector engagement during COVID19-WHO's approach. https://www.who.int/docs/default-sourc e/health-system-governance/role-of-who-in-covid-response. pdf?sfvrsn=9a5bcde0_2.

Ying, Xiu. 2020. ALERJ Wants Intervention in Rio's Private Hospitals Refusing to Treat Covid-19 Patients. The Rio Times. https://rioti mesonline.com/brazil-news/miscellaneous/covid-19/alerj-wants -intervention-in-rios-private-hospitals-refusing-to-attend-coron avirus-infected-patients/.

Youde, J. 2016. Private actors, global health and learning the lessons of history. Medicine, Conflict and Survival 32 (3): 203-220.

Publisher's Note Springer Nature remains neutral with regard to jurisdictional claims in published maps and institutional affiliations. 